\title{
Effect of Titanium Hardness on the Integrity and Stress Concentration of External Hexagon Dental Implants
}

\author{
Efecto de la Dureza del Titanio Sobre la Integridad y la \\ Concentración de Estrés de los Implantes Dentales Hexágonos Externos
}

\begin{abstract}
Alecsandro de Moura Silva'; Jefferson David Melo de Matos ${ }^{1,2}$; João Paulo Mendes Tribst'; Guilherme da Rocha Scalzer Lopes²; Carolina da Silva Machado Martinelli²; Alexandre Luiz de Souto Borges²; Estevão Tomomitsu Kimpara²; Lafayette Nogueira Junior²; Renata Marques de Melo² \& Marco Antonio Bottino ${ }^{2}$
\end{abstract}

SILVA, A. M.; MATOS, J. D. M.; TRIBST, J. P. M.; LOPES, G. R. S.; MARTINELLI, C. S. M.; BORGES, A. L. S., KIMPARA, E. T.; NOGUEIRA JR, L.; DE MELO, R. M. \& BOTTINO, M. A. Effect of titanium hardness on the integrity and stress concentration of external hexagon dental implants. Int. J. Odontostomat., 15(4):1053-1059, 2021.

ABSTRACT: The aim of this study was to evaluate the influence of overtorque on integrity, strength and stress on external hexagonal implants $(E H)$, with two different grades $(N=10)$ : conventional $(C)$, grade 4; and modified (M), grade 4 with thermal treatment. The dimensions of EH were $3.75 \times 13 \mathrm{~mm}$; the specimens were fixed and submitted to SEM analysis and image acquisition. The abutment was then retained with $70 \mathrm{~N} / \mathrm{cm}$, re-analyzed by SEM, and a second image was obtained. The images were analyzed by Image $\mathrm{J}$ software $(1.44 \mathrm{o}-\mathrm{NIH}$, USA) for dimensional variations measurement on surface of the hexagonal area. The finite element method was applied with a similar compliance to calculate the resultant stress (MPa) during the torque. Results were statistically analyzed with t-student test (5\%). The dimensional accuracy of $\mathrm{M}$ $\left(0.22 \mathrm{~mm}^{2}\right)$ was statistically significant $(\mathrm{p}<0.05)$. Minimum principal stress and von-Mises stress of C $(-19.95 \mathrm{MPa},-19.94$ $\mathrm{MPa}$ ), were lower than $\mathrm{M}$ values (-55.83 MPa, -55.96 MPa), respectively. However, the M group showed lower deformation than $\mathrm{C}$ group. Therefore, more rigid titanium alloy is a promising alternative to avoid plastic deformation of prosthetic connections even concentrating higher stress magnitude on its structure.

KEY WORDS: dental implants, finite element analysis, dental alloys.

\section{INTRODUCTION}

In contemporary dentistry, the use of osseointegrated dental implants for rehabilitation of patients continued to expand as treatment option for both single and multiple rehabilitation (Adolfi et al., 2020; Matos et al., 2020; Silveira et al., 2021).

The increase in the use of single implants has resulted in several studies, and the most reported biomechanical complications are the precision fit between the implant and abutment (Tribst et al., 2021), deformations of the hexagon surface (Romero et al., 2000; Renner, 2000; Khraisat et al., 2004; Segundo et al., 2007; Melo-Filho et al., 2019; Rodrigues et al., 2020), the rotational freedom between implant fixation and abutment (Bambini et al., 2005), dimensional changes and machining tolerances on prosthetics connections (Schulte, 1994; Malaguti et al., 2011), loosening or fracture of prostheses screws (Chen et al., 2021).

All of these factors are directly affected by the dental material with which implants are made. In general, implants are made of titanium (cp Ti) owing to its properties such as biocompatibility, mechanical resistance to fatigue and corrosion (Li et al., 2020).

According to the ASTM (F67), cp Ti is classified according to its hardness, being grade 1 the lowest

\footnotetext{
${ }^{1}$ Department of Dentistry, University of Taubaté (UNITAU), São Taubaté - SP, Brazil - SP, Brazil.

${ }^{2}$ Department of Dental Materials and Prosthodontics, São Paulo State University (Unesp), Institute of Science and Technology, São José dos Campos - SP, Brazil.
} 
hardness and grade 4 , the highest. Initially the manufacturers used cp Ti grade 2 to make implants; however, deformation has been reported on the implants connection (Bambini et al.).

Nowadays, the manufacturers successfully applied the CP grade 4 alloys, which have shown improved mechanical properties, such as higher elasticity modulus and high corrosion resistance (Bambini et al.), as mean to increase dimensional stability and avoid biomechanical complications.

Deformation occurs during the installation process. Throughout surgery, implants should be fixed using a maximum force that is easily surpassed by the professional. For Kwon et al. (2009), overtorque occurs when above $45 \mathrm{~N} / \mathrm{cm}$. Thus, deformation is a consequence of excessive torque (Bambini et al.) or a result of torquing with inadequate instruments (Kwon et al.).

Literature is scarce as to the information about deformation of external hexagon implants with different grades. Most studies (Khraisat et al., 2006; Kano et al., 2007; Malaguti et al.; Junqueira et al., 2013) state that prosthetic connections deformation is a result of overtorque between the abutment and the implant platform.

The purpose of this study was to evaluate, in vitro and in silico, the deformation caused by overtorque on external hexagon implant platforms manufactured with two different CP Ti grades. The hypothesis is that implants with higher grade will present higher microhardness and less deformation.

\section{MATERIAL AND METHOD}
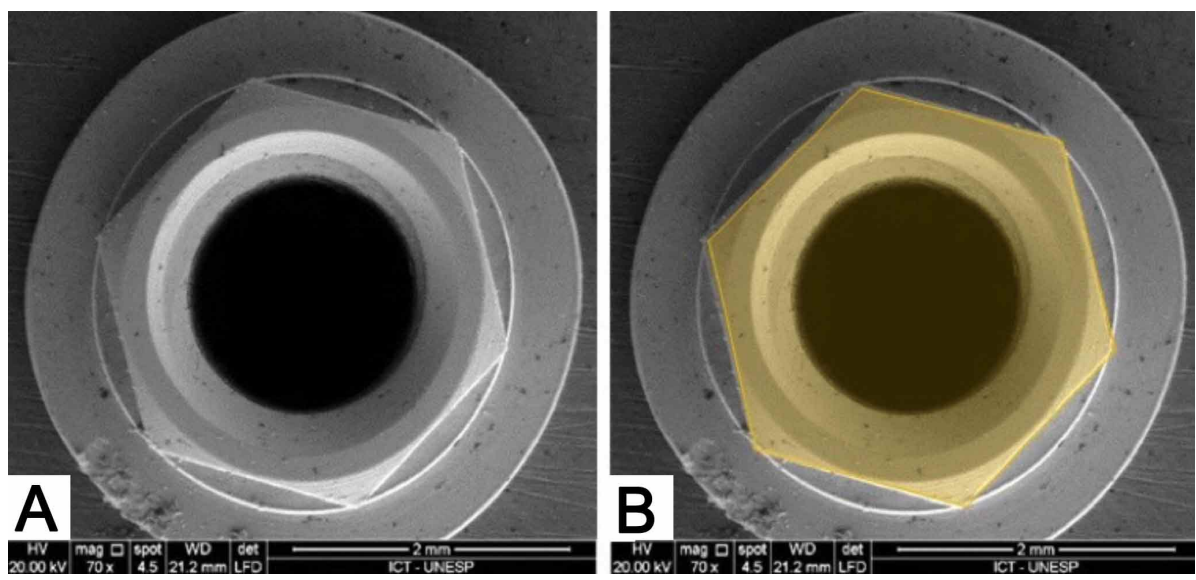

Fig. 1. A) Original SEM image; B) Delimitation of initial hexagonal area on Image software.
Scanning electron microscopy - SEM. Ten $(n=10)$ $\mathrm{CP}$ Ti external hexagons implants were used in this study (Conexão Sistema de Próteses, Arujá, São Paulo, Brazil). The implants were divided into two groups $(n=5)$ according to their hardness, specified by the manufacturer. The groups were named: Conventional $(C)$ - conventional implants made of grade $4 \mathrm{cp} \mathrm{Ti}$; and Modified (M) - implants made of grade 4 $\mathrm{cp} \mathrm{Ti}$, modified by the manufacturer through physical process.

All implants were positioned into a metallic matrix, identified and analyzed with a Scanning Electron Microscope (SEM - Inspect S50 - FEI Worldwide Corporate Headquarters, Oregon, USA) at $70 \times$ magnification rate. The images were exported to Image $\mathrm{J} \circledast$ software (Image Processing and Analysis in Java - National Institutes of Health - USA) and the surface measurements were performed (Fig. 1).

For image analysis, at the beginning of each measurement, calibration was performed using functions "Straight" and "Analyze - Set Scale". Subsequently, the total area measurement of the hexagon was performed using functions "Polygon Selections" and "Analyze - Measure".

For assembling simulation, a manual torque wrench was used (Connection Implant System, Arujá, São Paulo, Brazil), with maximum torque limit established at $70 \mathrm{~N} / \mathrm{cm}$. For overtorquing, $10 \%$ of this limit was exceeded; therefore, a torque of $77 \mathrm{~N} / \mathrm{cm}$ was applied.

Implants were connected to the assemblers and submitted to overtorque through a digital torquemeter (Lutron/TQ-8800). Implants were then positioned into a metallic matrix, identified and analyzed with SEM under the same magnification. The images were uploaded into Image $®$ (Wayne Rasband National 
Institute of Health, USA) for total area and angle measurement (AI2), using the same previously described methodology.

Afterwards, initial area (Al) was subtracted from post-torque area (AF), according to equation (1) below:

$$
D_{\text {resulting }}=A_{\text {initial }}-A_{\text {final }}
$$

A second step was performed to measure the average angle of the hexagon vertices. The vertices were identified and measured (QI) before torque. After torque, the vertices were again measured (QF). The resulting angle was calculated for each vertex (QR QI $=-\mathrm{QF}$ ) and the average angle was calculated for each hexagon. To measure the angles, "angle tool" and "measure" functions were used (Fig. 2).

The area and angle results were submitted to Anderson-Darling normality test and student's t-test. elements (Fig. 3). All materials were considered linear, elastic, homogeneous and isotropic. Young's modulus was 110 and $200 \mathrm{GPa}$ respectively to C and $\mathrm{M}$ implants.

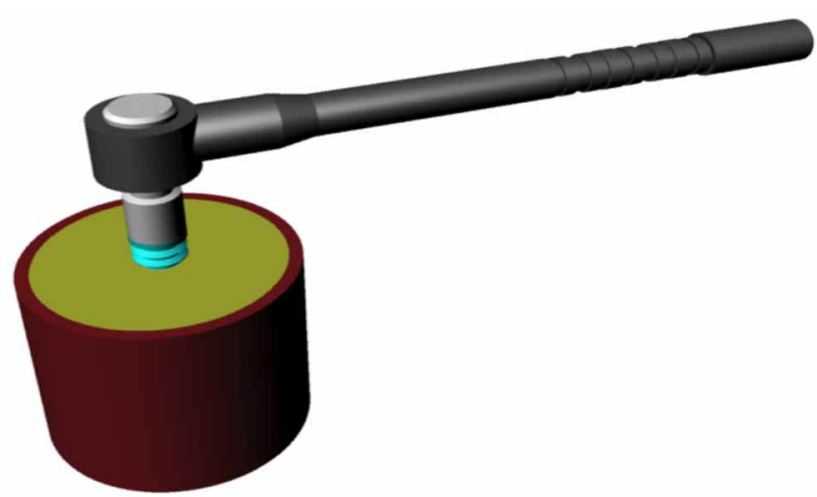

Fig. 3. Torque wrench and implant in the numerical model used in the present simulation.

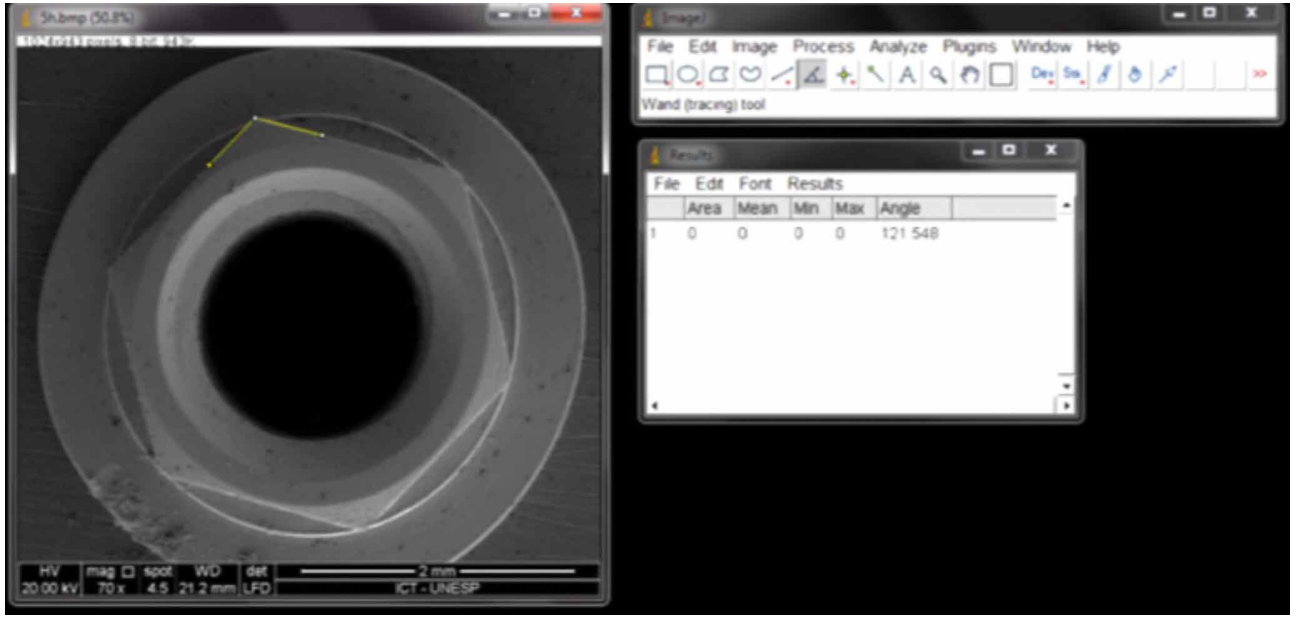

Fig. 2. Demonstration of hexagon angles measurement of specimens.

Microhardness. The Vickers microhardness of both materials was measured with a load of $19.614 \mathrm{~N}$ for 20 s (Microhardness tester HMV-2 Shimadzu Corp., Kyoto, Japan). The microhardness values were obtained from two samples of each material (four measurements into square specimens of $20 \times 20 \mathrm{~mm}$ ).

Finite Element Analysis. A 3D implant model was designed with CAD software (Rhinoceros 4.0 McNeel North America, Seattle, WA, USA), and exported to the computer aided engineering software ( ANSYS version 16.0, ANSYS Inc., Houston, TX, USA) where the experimental setup was performed. For that the mesh had 188.254 nodes and 106.976
A mesh convergence test was conducted and an element edge value that did not interfere with the results was set $(0.1 \mathrm{~mm})$. The contact interface between the implant and torque wrench allowed sliding but not the separation of these nodes (no separation). The implant base was fixed to the first threaded region to simulate experimental condition. A $70 \mathrm{~N}$ torque was applied and the static structural analysis was performed.

Stress maps with Minimum principal stress and von-Mises stress criteria were recorded and used to the models comparison. 
SILVA, A. M.; MATOS, J. D. M.; TRIBST, J. P. M.; LOPES, G. R. S.; MARTINELLI, C. S. M.; BORGES, A. L. S., KIMPARA, E. T.; NOGUEIRA JR, L.; DE MELO, R. M. \& BOTTINO, M. A. Effect of titanium hardness on the integrity and stress concentration of external hexagon dental implants. Int. J. Odontostomat., 15(4):1053-1059, 2021.

\section{RESULTS}

Area measument after overtorque. For each specimen, the differences between the initial and final hexagonal areas $(A R=A I-A F)$ are presented in Table I. When considering the numerical modulus, data were normally distributed $(p-$ value $=0.658)$.

Table I. Differences between the initial and final hexagonal areas per specimen, on each group.

\begin{tabular}{lc}
\hline Group & $\begin{array}{c}\text { Mean and Standard Deviation (SD) } \\
\left(\mathrm{mm}^{2}\right)\end{array}$ \\
\hline Conventional & $-0.178 \pm 0.055$ \\
Modified & $0.235 \pm 0.178$ \\
\hline
\end{tabular}

The Table shows positive and negative values, which resulted from sustained flow type. When the final area was greater than the initial (extension), a negative value was obtained; on the contrary, when there was a final area decrease (constriction), positive values were obtained, as per presented equation. The moduli of these values were used for the calculations because the materials present different ductility and different flow behavior. The results showed statistically significant difference between the different materials $(p=0.000)$.

Table II. Average reduction of complementary hexagon vertices angles.

\begin{tabular}{|c|c|}
\hline Group & $\begin{array}{c}\text { Mean }\left({ }^{\circ}\right) \text { and Standard Deviation } \\
(\text { SD) }\end{array}$ \\
\hline Conventional & $29.91 \pm 20.35^{\mathrm{A}}$ \\
\hline Modified & $6.01 \pm 5.57^{\mathrm{B}}$ \\
\hline
\end{tabular}

The material flow also varied according to the axis in which it occurred, vertical or horizontal. However, for this study, only the horizontal axis was considered. The means and standard deviations are shown in Table II; group values were statistically significant ( $p$-value = 0.008). The representative images of $C$ and $M$ groups are shown in Figure 4.

At a second stage, the reduction on the hexagons vertices angles was calculated after overtorque. In Table II, the mean and standard deviations are presented for both groups. Group C showed greater instability with larger standard deviation than the modified group, besides higher average variation.

Microhardness. The Vickers microhardness was significantly different between the materials $(p=0.000)$. The microhardness of $M$ specimens (304.8 \pm 19.26 $\mathrm{VHN}$ ) was significantly higher than the ones of group C $(247.67 \pm 14.99 \mathrm{VHN})$.

Finite Element Analysis. The model corresponding to $C$ group had higher minimum principal stress (MPS) which is about three times greater than the one found in the modified group. The stress distribution at group $C$ covered the entire hexagonal surface, whereas in group $M$, stress distribution was restricted to the vertices of the hexagon.

Similarly, von-Mises stress (MSS) was three times bigger in C, compared to M's. However, MSS of group C was concentrated at the hexagon vertices.

\section{DISCUSSION}
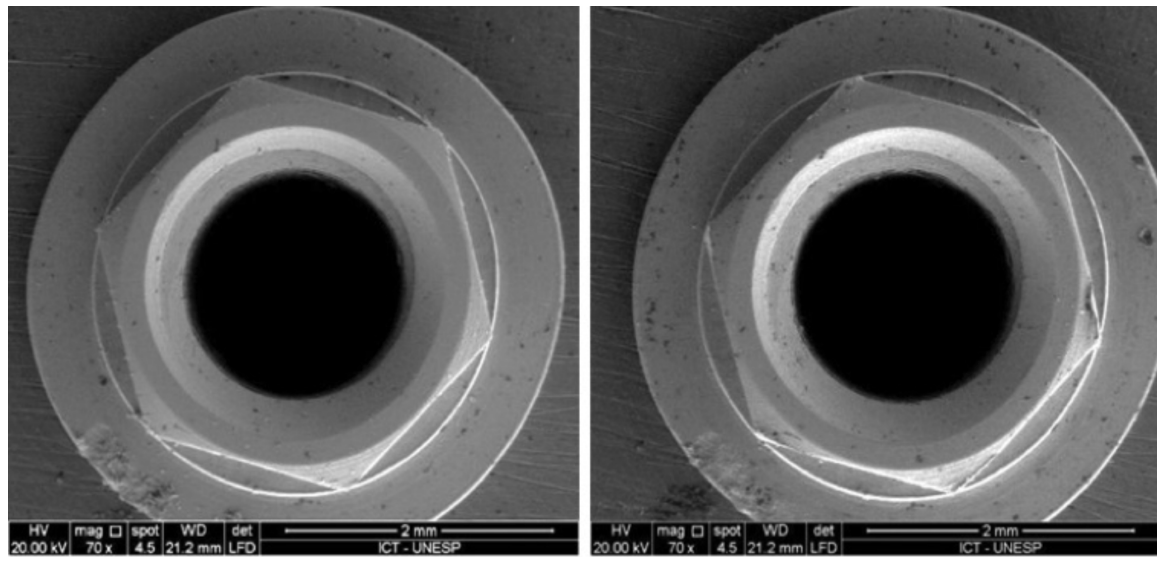

Fig. 4. Post-torque photomicrographs. Group M specimen; and group C specimen after overtorque, with evident deformation of hexagon vertices observed in the most flexible alloy implant.
Titanium $(\mathrm{Ti})$ is classified by its hardness grade, commercially pure and graded 1-4 according to ASTM F67. The cp Ti has tracing alloy element components only, which do not adversely affect its biological properties, but influences its mechanical properties. When implants started to be produced, they were made of $\mathrm{cp} \mathrm{Ti} \mathrm{grade}$ 2. Later, they started to be made of $\mathrm{cp}$ Ti grade 4, which has increased mechanical properties. In 2013 modified implants grade 4 , which have 

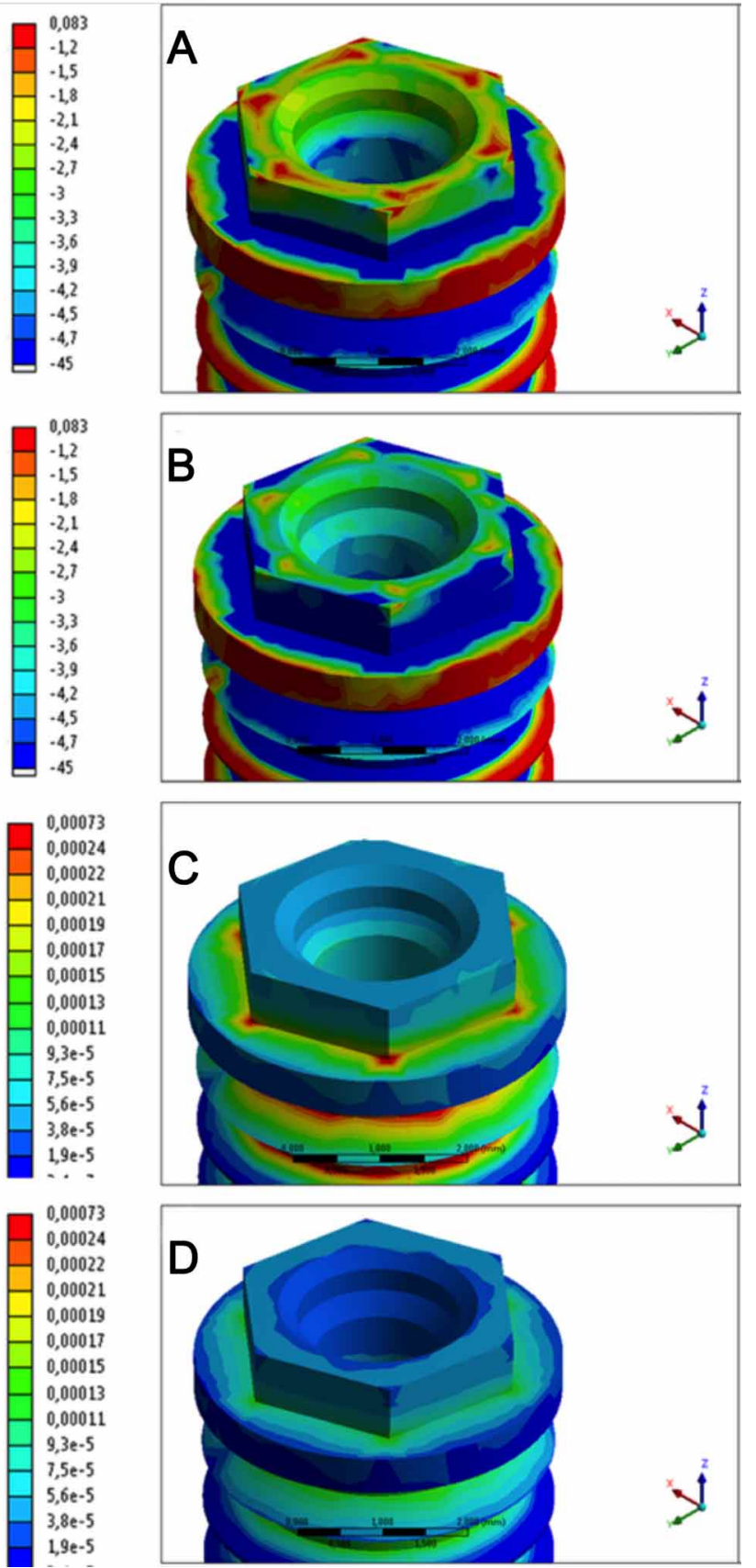

Fig. 5. Stress maps. A) Minimum principal stress with rigid alloy, C) Minimum principal stress with the flexible alloy, D) von-Mises stress with rigid alloy and F) von-Mises stress with flexible alloy.

higher elasticity modulus to $\mathrm{cp}$ Ti grade 4 standard, began to be commercially viable. In this study, the microhardness of two materials (conventional and modified) and both in vitro and in situ materials strains in the connection area of the implant external hexagon were tested.
Group M showed higher hardness than group C. The values obtained by $\mathrm{C}$ group are similar to those literature-evidenced (Faria et al., 2011, 2012), thus, the hardness values obtained by with M group are superior to those found in literature. This may have contributed to lower strain in $M$, tending to smaller change area. The same can be observed on hexagons vertices strain, wherein group $C$, strain was five times greater than $\mathrm{M}$.

The deformed hexagon angles may indicate greater rotation degree in this group, which may incur in various clinical disorders, including the contraindication for use in unitary cases. Moreover, several studies have found a correlation between rotational freedom and screw loosening at the abutment-implant interface (Malaguti et al.; Tribst et al., 2018, 2021). In the present study, a unique setting was presented, in which the implant connection was exposed to a $10 \%$ standard value overtorque.

Clinically, the EH implant connection may be repeatedly exposed to the condition of torque, installation processes, molding, casting tests and esthetics. These steps, when improperly performed, may compromise the hexagon vertices integrity. Thus, when overtorquing occurs frequently, the material behavior and implant assembly survival/ abutment become overestimated as versed in literature; and the freedom degree and torque loss become more severe than estimated.

It can be assumed that, in the initial torque application on abutments screws, as much as in the initial torque for implant fixing, part of the energy is consumed in the friction between the surfaces of the assembler and the hexagon and may result in micro deformations (Kano et al., 2006). When torque is applied on these surfaces as it was for the present study, it receives higher energy than the implant's elastic limit, resulting in plastic deformation as shown in Figures $2 \mathrm{~b}$ and $2 \mathrm{~d}$. This study observed, in vitro and in silico, that the higher the elasticity modulus, the lower is the plastic deformation and this confirms this study's hypothesis.

At the time of implant screw insertion into the receiver bone, the professional may often exceed the strength limit specified by the manufacturer, in the case, $70 \mathrm{~N}$, results which indicate that $\mathrm{C}$ group, showed higher stress at hexagons corners. In assorted implants, it was possible to ascertain larger 
plastic deformation with substrate disposal promoting greater mismatch of the prosthetic component (Melo-Filho et al.) whose study evaluated the external connection of dental implants with even greater rotation degree.

As in the primary insertion, strength could result in hexagon surface deformation and this was stricter in group C. Exacerbated by the effect described according to Kano et al. (2007), the induced stress on $\mathrm{EH}$ gaps and at the abutment implant intersection, could burnish the sharp gaps angles and rotate prosthetic crowns.

The linear statical analysis of the different implants showed that group $\mathrm{M}$ model had the higher stress concentration (Figs. 5a and 5b) in the hexagon corners (59.83 $\mathrm{MPa}$ ) than in the group $\mathrm{C}$ model (19.94 MPa). It is possible to predict, according to Von Misses analysis (Figs. $5 c$ and $5 d$ ), which vertices are deformed above material elastic limit and that deformation in group $\mathrm{C}$ will be more severe than in M (Theoharidou et al., 2008).

Even if the two studied materials showed statistically significant differences of hardness grades, it is possible that both materials display same microstructural configuration, due to their classification (both grade 4). In general, these materials have a phase only at room temperature (Ohkubo et al., 2003), which leads to more stability and more mechanical resistance. However, more studies are required to characterize structural and mechanical differences between these materials.

It was possible to conclude that the studied materials are mechanically different and that modified grade 4 was harder and, consequently, shows less plastic deformation even with high stress magnitude when subjected to overtorque. Therefore, this material can contribute to the reduction of rotational freedom and loosening of prosthetic screws.

\section{ACKNOWLEDGEMENTS}

The authors would like to thank the Conexão Sistema de Próteses, who gently provided the materials for this study and the São Paulo Research Foundation (FAPESP - grant number 2019/24903-6).
SILVA, A. M.; MATOS, J. D. M.; TRIBST, J. P. M.; LOPES, G. R. S.; MARTINELLI, C. S. M.; BORGES, A. L. S.; KIMPARA, E. T.; NOGUEIRA JR, L.; DE MELO, R. M. \& BOTTINO, M. A. Efecto de la dureza del titanio sobre la integridad y la concentración de estrés de los implantes dentales hexágonos externos. Int. J. Odontostomat., 15(4):10531059, 2021.

RESUMEN: El objetivo de este estudio fue evaluar la influencia del sobrepar en la integridad, la fuerza y la tensión en los implantes hexagonales externos $(\mathrm{EH})$, con dos grados diferentes $(N=10)$ : convencional $(C)$, grado 4 ; y modificado $(\mathrm{M})$, grado 4 con tratamiento térmico. Las dimensiones de $\mathrm{EH}$ eran 3,75 de diámetro $\times 13 \mathrm{~mm}$ de longitud; las muestras se fijaron y se sometieron a análisis SEM y adquisición de imágenes. A continuación, el pilar se retuvo con $70 \mathrm{~N} / \mathrm{cm}$, se volvió a analizar por SEM y se obtuvo una segunda imagen. Las imágenes se analizaron con el software Image J (1.44o-NIH, EE. UU.) Para medir las variaciones dimensionales en la superficie superior del área hexagonal, que fue causada por un par excesivo. El método de los elementos finitos se aplicó con un cumplimiento similar para calcular la tensión resultante (MPa) durante el par. Los resultados se analizaron estadísticamente con la prueba t-student (5\%). La precisión dimensional de $\mathrm{M}\left(0,22 \mathrm{~mm}^{2}\right)$ fue estadísticamente significativa $(p<0,05)$. La tensión principal mínima y la tensión de von-Mises de C (-19,95 MPa, -19,94 MPa), fueron inferiores a los valores de $\mathrm{M}(-55,83 \mathrm{MPa},-55,96 \mathrm{MPa})$, respectivamente. Sin embargo, el hexágono del grupo $\mathrm{M}$ mostró menor deformación que el grupo C. Por lo tanto, la aleación de titanio más rígida es una alternativa prometedora para evitar la deformación plástica de las conexiones protésicas incluso concentrando una mayor magnitud de tensión en su estructura.

PALABRAS CLAVE: implantes dentales, análisis de elementos finitos, aleaciones dentales.

\section{REFERENCES}

Adolfi, D.; Tribst, J. P. M.; Adolfi, M.; Dal Piva, A. M. D. O.; Saavedra, G. D. S. F. A. \& Bottino, M. A. Lithium disilicate crown, zirconia hybrid abutment and platform switching to improve the esthetics in anterior region: a case report. Clin. Cosmet. Investig. Dent., 12:31-40, 2020.

Bambini, F.; Memè, L.; Pellecchia, M.; Sabatucci, A. \& Selvaggio, R. Comparative analysis of deformation of two implant/ abutment connection systems during implant insertion. An in vitro study. Minerva Stomatol., 54(3):129-38, 2005.

Chen, J.; Wang, L.; Yang, L.; Zhang, X.; Huang, B. \& Li, J. The prosthetic screw loosening of two-implant supported screwretained fixed dental prostheses in the posterior region: a retrospective evaluation and finite element analysis. J. Biomech., 122:110423, 2021.

Faria, A. C.; Bordin, A. R.; Pedrazzi, V.; Rodrigues, R. C. \& Ribeiro, R. F. Effect of whitening toothpaste on titanium and titanium alloy surfaces. Braz. Oral Res., 26(6):498-504, 2012. 
SILVA, A. M.; MATOS, J. D. M.; TRIBST, J. P. M.; LOPES, G. R. S.; MARTINELLI, C. S. M.; BORGES, A. L. S., KIMPARA, E. T.; NOGUEIRA JR, L.; DE MELO, R. M. \& BOTTINO, M. A. Effect of titanium hardness on the integrity and stress concentration of external hexagon dental implants. Int. J. Odontostomat., 15(4):1053-1059, 2021.

Faria, A. C.; Rodrigues, R. C.; Claro, A. P.; Mattos, M. G. C. \& Ribeiro, R. F. Wear resistance of experimental titanium alloys for dental applications. J. Mech. Behav. Biomed. Mater., 4(8):1873-9, 2011.

Junqueira, M. C.; Silva, T. E.; Ribeiro, R. F.; Faria, A. C.; Macedo, A. P. \& De Almeida, R. P. Abutment rotational freedom evaluation of external hexagon single-implant restorations after mechanical cycling. Clin. Implant. Dent. Relat. Res., 15(6):927-33, 2013.

Kano, S. C.; Binon, P. P.; Bonfante, G. \& Curtis, D. A. The effect of casting procedures on rotational misfit in castable abutments. Int. J. Oral Maxillofac. Implants, 22(4):575-9, 2007.

Kano, S. C.; Binon, P.; Bonfante, G. \& Curtis, D. A. Effect of casting procedures on screw loosening in UCLA-type abutments. J. Prosthodont., 15:77-81, 2006.

Khraisat, A.; Abu-Hammad, O.; Al-Kayed, A. M. \& Dar-Odeh, N. Stability of the implant/abutment joint in a single-tooth externalhexagon implant system: clinical and mechanical review. Clin. Implant. Dent. Relat. Res., 6(4):222-9, 2004.

Khraisat, A.; Baqain, Z. H.; Smadi, L.; Nomura, S.; Miyakawa, O. \& Elnasser, Z. Abutment rotational displacement of external hexagon implant system under lateral cyclic loading. Clin. Implant. Dent. Relat. Res., 8(2):96-9, 2006.

Kwon, J. H.; Han, C. H.; Kim, S. J. \& Chang, J. S. The change of rotational freedom following different insertion torques in three implant systems with implant driver. J. Adv. Prosthodont., 1(1):3740, 2009.

Li, J.; Jansen, J. A.; Walboomers, X. F. \& Van den Beucken, J. J. Mechanical aspects of dental implants and osseointegration: A narrative review. J. Mech. Behav. Biomed. Mater., 103:103574, 2020.

Malaguti, G.; Denti, L.; Bassoli, E.; Franchi, I.; Bortolini, S. \& Gatto, A. Dimensional tolerances and assembly accuracy of dental implants and machined versus cast-on abutments. Clin. Implant. Dent. Relat .Res., 13(2):134-40, 2011.

Matos, J. D. M.; Nakano, L. J. N.; Silva, S. A. B. D.; Nascimento, J. A. D.; Aureliano, G. M. G.; Andrade, V. C. \& Lopes, G. R. S. Homogenous Bone Grafts as an Alternative in Oral Rehabilitation Treatments with Dental Implants. Int.J. Odontostomat., 14(4):67884, 2020.

Melo-Filho, A. B.; Tribst, J. P. M.; Ramos, N. C.; Luz, J. N.; Jardini, M. A. N.; Borges, A. L. S.; Santamaria, M. P. \& Melo, R. M. Failure probability, stress distribution and fracture analysis of experimental screw for micro conical abutment. Braz. Dent. J., 30(2):157163,2019

Ohkubo, C.; Shimura, I.; Aoki, T.; Hanatani, S.; Hosoi, T.; Hattori, M.; Oda, Y. \& Okabe, T. Wear resistance of experimental Ti-Cu alloys. Biomaterials, 24(20):3377-81, 2003.

Renner, A. M. Fabrication of implant overdentures that are passive and biocompatible. Implant. Dent., 9(1):96-101, 2000.

Rodrigues, V. A.; Dal Piva, A. M. O.; Yamaguchi, C. A.; Borges, A. L. S.; Mukai, M. K. \& Tribst, J. P. Effect of framework type on survival probability of implant-supported temporary crowns: An in vitro study. J. Clin. Exp. Dent., 12(5):e433-9, 2020.

Romero, G. G.; Engelmeier, R.; Powers, J. M. \& Canterbury, A. A. Accuracy of three corrective techniques for implant bar fabrication. J. Prosthet. Dent., 84(6):602-7, 2000.

Schulte, J. K. External hex manufacturing tolerances of six implant systems: a pilot study. Implant. Dent., 3(1):51-3, 1994

Segundo, R. M.; Oshima, H. M.; Silva, I. N.; Júnior, L. H.; Mota, E. G. \& Coelho, L. F. Stress distribution on external hexagon implant system using $3 \mathrm{~d}$ finite element analysis. Acta Odontol. Latinoam., 20(2):79-81, 2007.

Silveira, M. P. M.; Campaner, L. M.; Bottino, M. A.; Nishioka, R. S.; Borges, A. L. S. \& Tribst, J. P. M. Influence of the dental implant number and load direction on stress distribution in a 3-unit implant-supported fixed dental prosthesis. Dent. Med. Probl., 58(1):69-74, 2021.
Theoharidou, A.; Petridis, H. P.; Tzannas, K. \& Garefis, P. Abutment screw loosening in single-implant restorations: a systematic review. Int. J. Oral Maxillofac. Surg., 23:681-90, 2008.

Tribst, J. P. M.; Dal Piva, A. M. O.; da Silva-Concílio, L. R.; Ausiello, P. \& Kalman, L. Influence of implant-abutment contact surfaces and prosthetic screw tightening on the stress concentration, fatigue life and microgap formation: a finite element analysis. Oral, 1:88-101, 2021.

Tribst, J. P. M.; Melo, R. M.; Borges, A. L. S.; Souza R. O. A. \& Bottino, M. A. Mechanical Behavior of Different Micro Conical Abutments in Fixed Prosthesis. Int. J. Oral Maxillofac. Implants, 33(6):1199-205, 2018.

Corresponding author:

Jefferson David Melo de Matos

D.D.S.; M.D.; Ph.D. Student.

Post Graduate Student - Ph.D Program

Department of Dental Materials and Prosthodontics

São Paulo State University (Unesp)

Institute of Science and Technology

São José dos Campos - SP.

Avenida Engenheiro Francisco José Longo, 777/778

Jardim São Dimas

São José dos Campos

SP, CEP: 12245000

BRAZIL

E-mail: matosjefferson19@gmail.com

ORCID: https://orcid.org/0000-0003-4507-0785 